\title{
会计统计核算一体化的研究分析
}

郭本默

沈阳科技学院

DOI:10.32629/ej.v2i4.206

[摘 要] 本文对会计核算与统计核算的基本概念进行阐述,从会计核算与统计核算的区别与联系展开分析,并以此为依据,提 出规范化财务核算活动, 搭建统一的数据交换端口; 合理利用信息化技术,引进统计分析方法; 规范会计统计核算原则, 提高财 务信息质量; 完善管理制度,实现统计会计核算一体化目标等几个方面的措施。希望企业在实际的运营过程中,紧跟时代的发 展脚步,加强财务管控力度,促进会计统计核算一体化,逐步创造出更高的经济效益,实现企业的长远发展目标。

[关键词] 会计核算; 统计核算; 管理制度; 信息化建设

目前, 我国的市场经济环境不断变化, 给各个企业带来 了一定的发展机遇与挑战, 导致财务管理过程中存在许多问 题。基于此, 只有创新管理体制, 开展统一的会计核算与统计 核算工作, 才能够避免风险问题发生。统计核算主要就是指 从宏观的角度进行核算, 其中包括企业的各项经营活动。会 计核算主要就是从微观的角度进行核算, 使管理者能够直观 的了解到财务运行状况, 并编制财务报表。不管是从核算目 的与对象进行分析, 都有密切的联系。通过促进两者的一体 化发展, 完善管理体系, 保证财务数据的有效性, 才能为企业 的重大经营决策提供依据。

\section{1 会计核算与统计核算的基本概念}

会计核算的基本概念就是对资金流量及材料使用情况 进行记录, 并展开财务分析。主要就是记录收支凭证, 开展会 计科目分类及成本核算等工作。针对于企业产生的经济成果 进行评价, 加强财务监督力度。统计核算作为国民经济核算 的重要表现形式, 开展分析与计量工作, 使用科学化的方式 进行整理统计与调查, 研究经济总量与企业的经济发展情 况。总体来说, 统计核算就是为基础的会计核算服务,有效扩 大核算范围, 进而保证经济过程核算的真实性与实效性。

\section{2 会计核算与统计核算的区别与联系}

2.1会计核算与统计核算的区别

2.1.1核算对象不同。会计核算主要就是在遵循会计准 则的基础上, 利用专门的程序方式对各项经济活动进行记录 与分析, 反映出企业的财务状况。因此, 企业应当以资金运动 为对象, 包括资金筹集、投放及收入分配等方面, 体现出价值 性与围观性特点。统计核算主要就是利用统计方法搜集资料, 并分析社会经济现象发展的基础工作。从企业的发展角度进 行分析, 对各项活动进行统计, 核算范围较广。

2.1.2核算方式不同。会计核算通过成本核算、资产清 查及复式记账等方式, 对各项活动进行全面记录, 并将企业 要素的变化情况展现出来。但是利用统计会计就是利用抽样 调查法、综合指标法等方式, 了解活动的规模、结构等, 并对 数据进行整合计算, 找到其中的规律。

2.1.3核算过程利用的计量单位不同。企业会计核算使
用的计量单位有劳动计量单位、货币计量单位等, 更加强调 以计量货币为主, 合理开展会计核算, 在对原材料使用情况 进行核算的过程中, 就需要实物计量单位进行辅助, 并将材 料的使用情况展示出来。但是在统计核算的过程中,应当采 取实物计量的方式, 使用适当的量度, 使用的计量方式更加 广泛, 能够将货币无法展示出来的社会经济形象体现出来。

\section{2会计核算与统计核算的联系}

2.2.1首先, 会计核算与统计核算的目的都是为了促进 各项经营活动顺利开展, 并将真实的数据展现出来。核算基 础还应当将原始的数据作为基础内容, 并建立健全的核算体 系。就实际情况进行分析, 在开展会计核算的过程中, 使用了 许多统计方式, 在管理会计与审计工作中使用了统计指标、 分组等方式, 使会计信息的质量不断提升, 能够预测未来的 发展情况。

2.2.2在进行统计核算的过程中, 使用会计资料展开全 面的评价, 促进两者之间的融合, 不仅在一定程度上丰富了 统计学的内容, 还促进了统计核算方式的完善与发展。最后, 使统计核算的职能不仅仅局限于报表编制, 而是能够开展统 计分析预测, 对业务活动进行计量, 在两者的相互补充背景 下, 明确会计主体, 促进后续活动的开展。

\section{3 会计核算与统计核算的一体化路径}

3. 1 规范化财务核算活动, 搭建统一的数据交换端口

企业要想有效提高财务管理效率, 就要从管控各项经济 活动入手, 对原始的财务数据进行会计核算。不仅能够为经 营活动提供依据, 还能保证财务数据的真实性, 为后续的核 算与统计工作做好铺垫。通过规范化管理的方式, 建立完善 的会计统计核算一体化制度, 建立岗位责任制, 将核算目标 划分给工作人员, 保证其能明确自身的基本工作职责, 强调 对原始数据的审核与归档管理, 促进会计核算工作的顺利开 展。在此基础上, 定期进行岗位轮换, 建立统一的数据交换端 口, 完善会计核算信息系统。在进行财务报表的汇总与合并 过程中, 传统的财务软件核算形式已经无法满足企业的发展 需求。因此, 完善统一的数据交换端口, 能够促进统计核算与 会计核算的信息共享, 还能够有效提高工作效率, 促进后续 
经营活动的顺利进行。

3. 2 合理利用信息化技术, 引进统计分析方法

目前, 信息化技术得到了广泛的应用, 企业应当合理利 用计算机软件, 保证其能够解决财务问题, 还能够及时获得 财务核算信息, 不断提高企业的会计信息处理能力。结合当 前的财务管理要求, 对财务软件进行设计与调整, 对财务管 理软件进行辅助, 保证各项经营决策的合理性。利用财务软 件进行初始化统计, 对其中的统计模块进行分析, 掌握不同 功能的使用方式, 还要结合企业的发展目标, 设置权限, 不同 岗位的功能组人员设置相应的权限, 将财务软件的使用效益 发挥到最大化。通过在会计领域中引入统计分析方式, 能够 对各项活动进行监督与管控。在开展财务管理工作的过程中, 会计核算就要建立在会计动态要素基础上, 了解资产、负债 等情况, 还要了解资金来源的分布情况。在完善会计核算工 作的过程中, 统计分析方式也要不断变化。通过统计分析与 预测的方式, 引进适当的统计方法, 结合会计核算数据、资产 负债表等对企业的成本进行预测, 避免不必要的经济损失, 创造出更高的经济价值。

\section{3 规范会计统计核算原则, 提高财务信息质量}

要想促进财务会计与统计会计的一体化发展, 就要从会 计统计核算指标、计算路径、统计指标等方面入手, 找到两 者之间的共同语言。如现行的会计制度中的 “存货” 与统计 中的 “储备资产” 就有相似之处, 其核算的内容与方式也一 样, 针对于统计核算与会计核算之间的差异, 应当注意相互 补充与协调。通过增加与调整会计核算中的增值内容, 完善 经济核算体系。在编制企业资产负债表的过程中, 应当设立 一些独立的项目, 为统计核算提供数据资料, 解决统计核算 与会计核算之间分类方法不协调的问题。在增加智能的过程 中, 应当将员工、政府及债权人对企业的贡献展现出来, 对这 项指标进行核算, 不断扩大统计核算的范围, 加强会计固有 职能, 促进经济核算与统计核算的一体化发展。在减少会计 核算与统计核算时间的基础上, 提高数据的处理速度。利用 统计核算的方式, 将会计核算数据展示给需要的财务人员, 为企业制定明确的发展目标, 从根本上提高财务信息质量。
3. 4完善管理制度, 实现统计会计核算一体化目标

由于现代社会发展十分迅速, 市场竞争愈发激烈。企业 要想占据绝对的主体地位, 就要转变传统的财务核算工作, 完善管理机制, 根据企业的实际情况, 制定相对具体的制度 分支。例如, 在企业内部开展会计集中核算工作, 处于会计责 任主体不改变的前提下, 将部门预算等财政改革政策进行结 合。与此同时, 还要保证财务部门的工作具有一定的弹性, 相关的工作人员能够在实际的工作中洞察财务风险问题, 并 及时作出应对措施, 要保证会计人员根据原始凭证进行规范, 对于原始凭证要进行完整的填写, 规范化书写记账凭证与账 簿。会计核算与统计核算能够实现互相利用资料, 在一定程 度上减少成本的支出, 保证核算预估的准确性。最后, 借助我 国政府的力量支持统计核算与会计核算, 从各个方面入手, 推进一体化的建设进度。

\section{4 结束语}

综上所述, 企业大部分管理人员都已经意识到了会计核 算与统计核算相结合的重要意义, 但是在开展各项经营活动 的过程中, 还存在许多问题。所以, 企业应当加强财务管理力 度, 融合先进的信息化技术, 开展统计分析工作, 保证数据的 准确性。在此基础上, 实现二者之间的融合, 完善监督管控体 系, 有效提高核算效率, 提升企业的核心竞争力, 在多变的市 场环境中占据有利地位。

\section{[参考文献]}

[1]于晶雪.浅析企业的会计核算与统计核算的关系 [J]. 商场现代化,2011(15):141.

[2]时秀梅,胡福强,李明. “统计一会计”结合视角下制造 企业物流成本核算方法研究[J].会计师,2018(18):26-27.

[3]姜玲.国有企业会计核算与统计核算的关系与协调探 究[J]. 时代金融,2017(18):94+96.

[4]程平,施先旺,赵化.基于业财一体化的权益性筹资活 动大会计研究[J].财会月刊,2018(03):3-8.

[5]林凌霄.我国中小企业会计核算现状分析及对策研究 [J].吉林金融研究,2018(03):36-38. 